\title{
The Interaction Effect of Information Systems of Shipping and Logistics Firms and Managers' Support for Blockchain Technology on Cooperation with Shippers for Sustainable Value Creation
}

\author{
Hee-sung Bae (D)
}

Department of International Trade, Kyonggi University, Suwon 16227, Korea; hsbae@kyonggi.ac.kr

check for updates

Citation: Bae, H.-s. The Interaction Effect of Information Systems of Shipping and Logistics Firms and Managers' Support for Blockchain Technology on Cooperation with Shippers for Sustainable Value Creation. Sustainability 2021, 13, 4493. https://doi.org/10.3390/su13084493

Academic Editors: Marc A. Rosen and Manuel Rodríguez-Díaz

Received: 10 March 2021

Accepted: 15 April 2021

Published: 17 April 2021

Publisher's Note: MDPI stays neutral with regard to jurisdictional claims in published maps and institutional affiliations.

Copyright: (C) 2021 by the author. Licensee MDPI, Basel, Switzerland. This article is an open access article distributed under the terms and conditions of the Creative Commons Attribution (CC BY) license (https:// creativecommons.org/licenses/by/ $4.0 /)$.

\begin{abstract}
Firms apply new technology to value creation. In particular, blockchain technology increases transparency and stability of shipping and logistics firms and this is connected with a high level of collaboration with shippers. In this regard, the objective of this study is to verify the interaction effect of information systems of shipping and logistics firms and managers' support for blockchain technology on cooperation with shippers. To achieve the objective, this study identified variables based on prior research and analyzed the data collected by a survey. The results are as follows. First, information systems as a resource of shipping and logistics firms have a positive effect on cooperation with shippers. To enhance the strategic resource, they increase cooperation with shippers based on learning and logistics process improvement. Therefore, the relationship between the information systems and cooperation with shippers can be explained as a resource-based view. Second, there is the interaction effect of the information systems and managers' support for blockchain technology on the cooperation and this can be explained as a resource-based view. Information systems are resources of shipping and logistics firms, and managers should encourage and reward staff for using new technology such as blockchains, followed by a high level of cooperation with shippers.
\end{abstract}

Keywords: managers' support; blockchain technology; information systems; cooperation; shipping and logistics firms

\section{Introduction}

Firms buy cheap and quality raw materials, produce goods in low-cost countries, and sell the goods to the world market because the value chain is globalized [1]. This is connected with the value creation process, and shipping and logistics firms are regarded as links from the viewpoint of network theory. They add value to supply chains of shippers as nodes, and when the supply chains to which value is added can be managed by shipping and logistics firms, sustainable value can be created.

For sustainable value creation, Korean shipping and logistics firms use blockchain technology in their processes. The technology can solve present problems and create value in the future. This is connected with creating sustainable innovation of firms. In particular, the applications of blockchain technology in supply chains allow reliable and transparent transaction such as fair trade because it is possible to cooperate with participants in supply chains as well as prevent hacking through information sharing. Therefore, firms which apply blockchain technology to supply chain management can create sustainable value because works that occur in supply chains are transparently open to participants.

Research on information systems has been performed from various viewpoints. In particular, prior research verified that information systems as resources of firms have an important role to enhance performance [2]. On the other hand, prior research identified that there is a time lag between applications of information systems and performance 
improvement [3]. To reduce the time lag, firms enhance the relationships between information systems and performance on the basis of educating staff for information systems and creating reward systems for the use of information systems. Various research papers on information systems are almost all focused on manufacturing firms. Research on information systems of shipping and logistics firms has also been performed. This provides shippers with various services based on the use of information systems such as transport contracts, cargo tracking, inland transport, and electronic documents. The information systems can create various relationships with shippers. In this regard, the information systems have a positive influence on cooperation with shippers [4]. In addition, there is a need for research on the role of managers' support for blockchain technology in information systems of shipping and logistics firms and cooperation with shippers on the basis of changes in the technological environment.

Prior research explained information systems from various viewpoints. Prior research approached it from the viewpoint of supply chains [5], explained it as an antecedent factor that promotes cooperation in the network [6], and verified it as playing an important role in the relationships between participants in the integrated business processes [7]. Moreover, prior research identified that it directly affects supply chain integration, which is connected with manufacturing performance [8]. In addition, the factors which affect performance in supply chains are identified as blockchain technology [9] and cooperation [10,11]. Therefore, prior research verified that information systems have a direct influence on performance.

Despite the above results, prior research has the following limitations. First, blockchain technology is one of the core technologies in the fourth industrial revolution and it can add value to shipping and logistics firms. However, there is a lack of research concerned with the introduction and applications of blockchain technology in the shipping and logistics firms. Value creation of firms can be achieved by improving relations with partners as well as internal innovation. In this regard, it is important to conduct research on the relationships between blockchain technology of shipping and logistics firms and collaboration with shippers.

Second, shipping and logistics firms grasp the needs of shippers and use these to improve logistics processes. However, research on the resources of shipping and logistics firms to build a relationship with shippers has not yet been done. In particular, research on information systems as resources of the firms and cooperation with shippers can provide the direction to applicable methods of information systems.

Third, there is a lack of research on the factors which enhance the relationships between information systems of shipping and logistics firms and cooperation with shippers. Shipping and logistics firms provide shippers with logistics services which have the different characteristics compared with logistics activities of manufacturing firms. Information systems are excellent internal resources for shipping and logistics firms because they are the factor to enhance cooperation with shippers. However, there is no research on the factor to enhance the relationships between information systems and cooperation in the rapid change of the technological environment. In particular, from the viewpoint of managers, the change in the technological environment means the emergence of new technology, and they should suggest methods to apply it to business processes. In this regard, they need to confirm the factors which interact with information systems which affect cooperation with shippers. Therefore, the aim of this study is to verify the interaction effect of information systems of shipping and logistics firms and managers' support for new technology such as blockchains on cooperation with shippers.

\section{Literature Review}

\subsection{Information Systems of Shipping and Logistics Firms}

Research on information systems was performed from various viewpoints. Prior research verified that information systems positively affect performance $[3,8]$. The research shows various viewpoints from the functional level to the corporate level. Moreover, research on information systems concerned with logistics points out the importance of 
information management for improvement of customer service and efficient logistics operations [12]. Logistics information is revealed by various sources such as information on delivery, cargo location tracking, inventory, sales volume, and reverse logistics. There are various information systems to process logistics information such as points of sale, barcodes, value added networks, electronic ordering systems, radio frequency identification, and blockchain technology. In addition, logistics activities of manufacturing firms are performed by cooperation with logistics firms as service providers, and logistics firms raise a level of cooperation through connection of information systems with shippers as customers.

Information systems to process logistics information can be approached to a functional level rather than a corporate level, and shippers and logistics firms cooperate with each other through the connection of information systems. The definitions of information systems show various viewpoints. First, the hardware viewpoint of information systems is defined by Chiu [12], Closs and Xu [13], and Lee and Kim [14]. They defined it as hardware such as points of sale, barcodes, electronic data interchange, value added networks, electronic ordering systems, tracking systems, and radio frequency identification. The definition explains information systems as infrastructure for processing logistics information. Second, the definition of a managerial aspect on information flows is shown by Bian et al. [15], Chen et al. [16], Chow et al. [17], Lambert et al. [18], and Yeh et al. [19]. They explain information systems focused on processing and transmission of information. The research focused on information management but passed over the infrastructure. Third, an integrated explanation of information systems is suggested by Jeffers [20], Leek [21], and Yoon [22]. They explain information systems as a combination of hardware for collecting information and software for managing information flows. The definitions focus on the construction of information systems from the internal viewpoint of firms in the past and this stresses the importance of efficient information processing. By contrast, information systems are of importance in the connection with partners as well as departments in the present, and shipping and logistics firms use the information for transparent and efficient information processing because it is connected with blockchain technology as a decentralized system.

From the viewpoint of shipping and logistics firms, information systems mean integrated information management systems to provide information which shippers want in real time and to manage logistics processes of shippers. The systems provide necessary information for shippers as customers because of processing information of shippers as information providers, and as a result, the information systems should be built in the direction of strengthening the level of cooperation between shipping and logistics firms and shippers. Shipping and logistics firms which have superior information systems can provide information which shippers want, followed by enhanced cooperation between them. Shippers depend on logistics services of shipping and logistics firms for acquiring necessary resources and distributing final goods. As a result, information systems play a key role in the relationship between shipping and logistics firms and shippers. As the level of cooperation through information systems increases, shippers become more dependent on shipping and logistics firms. This is explained by core competence management. Through cooperation based on information systems, shippers focus on production and shipping and logistics firms focus on logistics. Therefore, they can enjoy synergy effects because of the core competence connection.

\subsection{Managers' Support for Blockchain Technology}

Research on blockchain technology is not active in port logistics processes. Prior research verified that blockchain technology is applied to supply chain management $[23,24]$ and port logistics processes [25-27]. Jabbar and Bjørn [26] identified the applications of an electronic bill of lading through using blockchain technology in the shipping and logistics sectors. They insisted that participants such as shippers, liners, forwarders, and port logistics firms in port logistics processes use the technological infrastructure based 
on blockchain when they draft the contracts and this is connected with the hyper ledger fabric developed by Maersk Line and IBM which is an information technology company. Koji [27] asserted that shippers and liners can use blockchain technology to acquire the document of title of a bill of lading, and the problem of overlapped use of a bill of lading can be solved by transferring rights through tokens. In addition, prior research found that blockchain technology is the key factor of collaboration among partners in supply chains [24]. Bag et al. [23] insisted that there are two barriers in the adoption of blockchain technology: "lack of management vision" and "cultural differences among supply chain partners". Particularly, cooperation is the key factor in supply chains, and managers have an important role in using blockchain technology.

Managers are the keys in decision making in the whole aspect and the subject of management that runs each department in tactical and operational aspects. The recognition of staff with respect to the goal of firms is strengthened by stressing of managers, and managers perform management and operation of departments through learning and contacting with staff. In particular, shipping and logistics firms need to essentially treat cooperation with shippers as well as inter-departmental cooperation. They should perform logistics management of shippers on the basis of inter-organizational information systems such as blockchain technology, followed by attaining firm performance. In this regard, blockchain technology is an important tool which increases a level of cooperation with shippers. In particular, managers' support for blockchain technology is regarded as a key factor concerned with enhancing cooperation with partners in supply chains because it stimulates the intention of staff.

Prior research classified cooperation into the structures and levels of decision making [28]. The role of top management is important in decision making from the strategic viewpoint, and managers support cooperation from the tactical and operational viewpoints. Similarly, cooperation with shippers is concerned with strategic decision making from the viewpoint of shipping and logistics firms and this is performed by the intention of top management. Cooperation with shippers is also implemented through learning and training of staff by managers. Managers of shipping and logistics firms develop the processes concerned with methods to understand shippers' needs and create solutions to problems that may arise when working with shippers. Managers understand shippers' needs, confirm the levels of services which shippers require, and set the goals for cooperation and these are based on learning and training of staff. Managers make tactical and operational decisions about cooperation, and staff is managed by managers. Therefore, the behavior and attitude of managers are the important factors that affect cooperation with shippers.

The managers' recognition for new technology such as blockchains is connected with learning and training of staff, which are the basis for cooperation with shippers. Managers' support for blockchain technology creates cooperative relationships with shippers because the support allows positive recognition of staff with respect to blockchain technology and builds an atmosphere of cooperation. Managers can grasp and attain shippers' needs through the use of blockchain technology. Managers' recognition and support for blockchain technology are the basis for minimizing staff's resistance to the technology, expanding the base of the technology, and creating efficient and effective relationships with shippers. Managers need to emphasize three factors: cooperative attitude, operational methods, and training for learning blockchain technology. Cooperative attitude means that staff feels an emotional unity with shippers when managers encourage staff members who use blockchain technology. The technology is the basis for cooperative attitudes between shipping and logistics firms and shippers and attaining supply chain performance. Operational methods are explained as contacts and relations. Contacts based on blockchain technology between shipping and logistics firms and shippers result in the processes and levels of cooperative works and solutions when problems occur in inter-corporate activities. The technology builds efficient relationships between firms and this is the basis for achieving supply chain performance. Training related to the technology allows a high level of cooperation because of minimizing staff's resistance to the technology, allowing staff to 
adapt quickly to the technology and increasing staff's understanding of inter-corporate cooperation. Managers' recognition and support for blockchain technology in shipping and logistics firms increase the efficiency in working with shippers, improve the relationships between firms, and strengthen the level of cooperation.

\subsection{Cooperation with Shippers}

Supply chain management is recognized as one of the important management methods of firms. Supply chain management has become a more important competency for firms compared with logistics management of an operational level in the past. Supply chains mean the flow of goods and information to the all participants in procurement, production, distribution, and reverse logistics, from suppliers of raw materials to final customers, and because firms manage the flows, supply chain management is regarded as adding efficiency and effectiveness in the flows. Cooperation among suppliers, manufacturers, and distributors from the vertical viewpoint is important in supply chain management. In addition, from the horizontal viewpoint, logistics service providers play an important role in managing the flow of goods and information. In this regard, shipping and logistics firms manage global supply chains of shippers as customers, and as a result, they play an important role in adding efficiency and effectiveness in supply chains of shippers.

In a different aspect than supply chain management from the vertical viewpoint, supply chain management from the horizontal viewpoint can describe the relationship between shipping and logistics firms and shippers. The perspective of cooperation or integration as the most important factor in supply chain management was reported by Stevens [29]. Cooperation can divide the stages of development into inter-functional, internal, and external. Cooperation in supply chains represents interaction and collaboration [30]. Interaction emphasizes communication in the flow of information. This means that there is of importance to information exchange activities through communication. In contrast, collaboration means a high level of value sharing, mutual goals, and collaborative behavior. Collaboration is explained as effective, motivated, mutual, and shared processes in supply chains. It means the state and quality of collaboration between firms which perform integrated activities on the basis of the changes in technology in the environment [31]. Therefore, cooperation means cooperative works among firms from the viewpoint of corporate behavior, is regarded as shared culture from the viewpoint of corporative culture, and is defined as cooperative relationships from the viewpoint of inter-firm relationships [32].

On the basis of the definition of supply chain management, cooperation between shipping and logistics firms and shippers from the horizontal viewpoint is regarded as the cooperative relationship between firms. The relationship is supported by information systems. Firms recognize information systems as logistics resources and use them as weapons in competition [33]. From the vertical viewpoint, the core of supply chain management is cooperation among suppliers, manufacturers, and customers. In the supply chain, participants do not want to provide information to other participants, and if they need to share information, they have to decide at what level they should share it. In this regard, when they perform supply chain management from the vertical viewpoint, it is not easy to decide a control level of information. Even if they decide the control level, the problem of information leakage still exists. In contrast, supply chain management is concerned with managing the relationships between shipping and logistics firms and shippers from the horizontal viewpoint. The relationship means cooperation with shippers as customers of shipping and logistics firms. Shippers include supply chain participants such as suppliers, manufacturers, and distributors, and information which they provide can be controlled by shipping and logistics firms. As a result, by sharing only necessary information, they can perform efficient cooperation in supply chains. In this regard, shipping and logistics firms which manage and control information in supply chains act as managers to carry out global supply chain management on behalf of shippers as customers and this adds efficiency to the whole supply chains. Therefore, shipping and logistics firms use information systems in supply chains for cooperation with shippers, and the 
firms which use blockchain technology can collaborate with shippers with high quality compared to competitors.

\section{Hypotheses and Methodology}

\subsection{Hypotheses}

\subsubsection{Information Systems and Collaboration}

The relationships between information systems of shipping and logistics firms and cooperation with shippers can be explained by the resource-based view. Capability, information, and knowledge as resources of shipping and logistics firms help them implement strategy and this is connected with the improvement of efficiency and effectiveness [34]. Resources can be explained from various viewpoints, but core resources of firms mean strategic resources which contribute to making profits [35]. Moreover, the resources have the characteristics of strategic resources which are useful to firms, have rare value, are not easily imitated by competitors, and are not substituted as other resources in the market [36]. In addition, the resources are the basis for shipping and logistics firms to implement strategic actions, and the difference in the resources among firms is the basis for the difference in performance. In this regard, information systems have the capability to add value in supply chain processes have the characteristics of the resources.

Shipping and logistics firms acquire external information on environmental uncertainty and to minimize the uncertainty, they collaborate with shippers. There are two conditions for applications of information systems: one is a hardware capability from the viewpoint of infrastructure and the other is a technological capability from the viewpoint of superstructure [37]. Shipping and logistics firms which have the conditions can strategically apply information systems. Information systems are tools to help shipping and logistics firms implement a strategy. In particular, information systems enable internal dissemination of external information from the viewpoint of supply chain management [38]. Moreover, information systems provide customers with useful help for sharing information $[39,40]$. Similarly, information systems of shipping and logistics firms are useful for information sharing for supply chain management of shippers. Information sharing by information systems is the basis of standardization and enables partners in supply chains to cooperate with each other. The application of information systems on the relationships between shipping and logistics firms and shippers has a positive influence on an integrated logistics capability in supply chains, followed by high performance [41].

Information systems of shipping and logistics firms play an important role in not only the internal viewpoint but also the viewpoint of the relationships with shippers. Information systems of shipping and logistics firms are regarded as a capability of firms to cooperate with shippers. They can apply information of shippers by using information systems and this is connected with an integrated logistics capability, which is the basis of a competitive advantage. The capability of information systems plays an important role in cooperation with shippers.

Shipping and logistics firms would attain a competitive advantage in the market through the use of information systems. Information systems are applied as a tool to understand the needs of shippers and to attain the needs. The information systems reduce unnecessary activities of shipping and logistics firms and make it possible to cooperate with shippers beyond the realm of firms. Shippers can obtain good quality logistics services, and shipping and logistics firms can strengthen their capability to respond quickly to complex customer needs through the use of information systems [42]. As a result, shippers can attain low cost, high production, and process efficiency, and shipping and logistics firms can provide shippers with good quality of logistics services through efficient supply chain management for customers. Therefore, shipping and logistics firms remove overlap and inefficiency in the whole process and enjoy a high level of cooperation with shippers.

Hypothesis 1 (H1). Information systems of shipping and logistics firms positively affect cooperation with shippers. 
3.1.2. The Interaction Effect of Information Systems and Managers' Support for Blockchain Technology on Cooperation

Cooperation between shipping and logistics firms and shippers can be performed by education of staff by managers on the basis of strategic decision making of top management. Managers provide the directions for staff cooperation [30]. The interest and intervention of managers based on decision making of top management can make clear the intention of staff for cooperation with shippers.

Managers' support is the most important factor to attain successful cooperation between shipping and logistics firms and shippers [43]. Shipping and logistics firms can reflect the needs of shippers in their logistics processes and as a result, they can form an internal process for cooperation with shippers. Cooperation with shippers in the process can be improved by the support of information systems. Moreover, when new technology such as blockchain emerges, cooperation with shippers can be further strengthened through superior information systems and managers' support. However, firms could face organizational resistance such as resistance of staff to new technology and conflicts of staff beyond process change. To minimize the resistance, managers should exert the necessary powers and capability of persuasion to enable staff to embrace the new technology. The interest and intervention of managers are implemented to minimizing the conflicts and the resistance and suggesting clear goals on cooperation with shippers, and as a result, managers can motivate staff to collaborate with shippers.

Managers become subjects of activities and decision making in the functional level and act as the directors for staff. As a result, staff's resistance and conflicts with new technology such as blockchain are minimized by managers' support, followed by increasing cooperation with shippers. Managers' support has a positive influence on the activities and attitude of staff through management of an operational level concerned with cooperation and makes possible a high level of cooperation with shippers on the basis of information systems [30]. Managers provide staff with rewards and encouragement for cooperation with shippers. As a result, the staff grasps the needs of shippers and this is connected with process improvement. Managers enable cooperative operations beyond the domain of firms because the staff recognizes the value of cooperation with shippers at the operational level. Managers increase staff's applicable capability of information systems through support for new technology such as blockchains and this is the basis of enhancing cooperation with shippers. Therefore, the interaction of information systems and managers' support for new technology such as blockchains provides the synergy effect in cooperation with shippers.

Hypothesis 2 (H2). The interaction effect of information systems and managers' support for blockchain technology in shipping and logistics firms enhances cooperation with shippers.

\subsection{Methodology}

The objective of this study is to verify the interaction effect of information systems of shipping and logistics firms and managers' support for blockchain technology on cooperation with shippers. For achieving the objective, this study identified the relationships between the variables through prior research. The conceptual and operational definitions of the variables were obtained from prior research. The items of the questionnaire were proved to have internal validity by verification of nine experts, three professors, three researchers, and three workers, who have worked for more than ten years in the port logistics fields.

The population is shipping and logistics firms which mean liners and international freight forwarders, and the sample frame is the membership lists of the Korea Shipowners' Association and Korea International Freight Forwarders Association. The responding firms were chosen in the lists, and the questionnaire was sent out to 1000 firms. The researcher called the responding firms before the survey, and if they wanted to answer the questionnaire, the questionnaire was sent to the firms by email. The survey was performed from December 2019 to February 2020, and 165 data points were collected. 
In the data, single responses or unfaithful responses, which were four responses, were excluded, and 161 data points were used in the analysis. Next are the conceptual and operational definitions of the variables.

This study has three variables: information systems of shipping and logistics firms, managers' support for blockchain technology, and cooperation with shippers. Information systems are the integrated concept of information systems to add value in logistics processes of shipping and logistics firms $[35,44]$. There are seven items on information systems. Managers perform whole operations for management of firms, encourage staff for cooperation with shippers, and lead cooperative attitudes of staff by providing rewards [30]. They make an effort to minimize staff's resistance and conflicts on the basis of improving logistics processes and educating staff through support for new technology such as blockchains. There are five items on managers' support for new technology such as blockchains. Cooperation means operational cooperation in the relationships with shippers $[45,46]$. This represents the degree of operational cooperation of shipping and logistics firms to work with shippers. There are seven items on cooperation with shippers. All items are measured by the perception of a respondent to use such a scale. Operational definitions of the above variables are shown in Appendix A.

\subsection{Analytical Methods}

The collected data were analyzed for reliability and validity and then the hypotheses were tested. Internal validity of the questionnaire was tested as interviews with experts, reliability was verified by Cronbach's alpha coefficients, and validity was identified by factor analysis. If Cronbach's alpha coefficient is higher than 0.7 , reliability is good. The results of an exploratory factor analysis need to exceed 0.5 in factor loading coefficients to be classified into only one factor, to exceed 1.0 in terms of eigenvalues, and to be less than $50 \%$ in the coefficient of variation. In addition, Kaiser-Meyer-Olsen (KMO) and Bartlett tests were analyzed, and there were no problems if KMO exceeded 0.5 , and an alternative hypothesis was supported in the results of the Bartlett test. Common method bias was tested by the Harmon's single factor method in SPSS. In addition, construct validity was divided into convergent validity and discriminant validity. The former can be analyzed by confirmatory factor analysis [47] and the latter can be identified by comparing the average variance extracted (AVE) with the square of the correlation coefficient [48]. If AVE is higher than the square of the correlation coefficient, the discriminant validity is good.

If there are no problems in the results of reliability and validity, hypotheses can be tested. The hypotheses were analyzed by a moderated regression analysis (MRA) that verifies the hypotheses by comparing the three models. First, model I is $Y=\alpha+\beta 1 X+\varepsilon$. Second, model II is $Y=\alpha+\beta 1 X+\beta 2 W+\varepsilon$. Third, model III is $Y=\alpha+\beta 1 X+\beta 2 W+\beta 3 X W+\varepsilon(Y=$ cooperation, $\mathrm{X}=$ information systems, $\mathrm{W}=$ managers' support, and $\mathrm{XW}=$ an interaction variable). If the R square of model III is higher than the R squares of Model I and II and an interaction variable is supported, there is an interaction effect of information systems of shipping and logistics firms and managers' support for new technology such as blockchain on cooperation with shippers. Next are the results.

\section{Results}

\subsection{The Information on Respondents}

To achieve the objective, this study collected and analyzed 161 data points. The results are shown below.

Table 1 shows the characteristics of the firms which responded to the questionnaire. Annual turnover represents 60 firms (37.3\%) with less than U\$1 million and seven firms (4.4\%) with an annual turnover between U\$5 and U\$10 million. There are two types of businesses: liners, i.e., 69 firms (42.9\%), and international freight forwarders, i.e., 92 firms (57.1\%). With respect to the number of employees, the highest is 57 firms $(35.4 \%)$ with less than 10 persons and the lowest is 15 firms (9.3\%) that did not respond. There are various 
annual turnovers, the type of business, and the number of employees in the shipping and logistics firms which responded to the questionnaire.

Table 1. The Information on Respondents.

\begin{tabular}{cccc}
\hline $\begin{array}{c}\text { Annual Turnover } \\
\text { (U\$1 Million) }\end{array}$ & Frequency (\%) & Type of Business & Frequency (\%) \\
\hline & $60(37.3)$ & Liners & $69(42.9)$ \\
less than 1 & $21(13.0)$ & Forwarders & $92(57.1)$ \\
$1-3$ & $20(12.4)$ & Employee (person) & Frequency (\%) \\
\cline { 3 - 4 }-5 & $7(4.4)$ & Less than 10 & $57(35.4)$ \\
$5-10$ & $15(9.3)$ & $10-30$ & $25(15.5)$ \\
$10-50$ & $26(16.1)$ & $30-50$ & $42(26.1)$ \\
over 50 & $12(7.5)$ & over 50 & $22(13.7)$ \\
No answer & & No answer & $15(9.3)$ \\
& $161(100.0)$ & Total & $161(100.0)$ \\
\hline Total & & &
\end{tabular}

\subsection{Results of Reliability and Validity Tests}

Three variables were used in the study: information systems of shipping and logistics firms, managers' support for new technology such as blockchains, and cooperation with shippers. The results of reliability and validity analyses of the variables are shown as follows.

Table 2 shows the result of reliability and validity analyses of the measuring items. The results of the exploratory factor analysis are good. As a result of confirmatory factor analysis, convergent validity is good because the model fit indices are higher than the criteria. Discriminant validity is good because AVE is higher than the square of the correlation coefficient. In addition, the common method bias was tested by the Harmon's single factor method in SPSS. The result is that the percentage of variance is 47.273 , which is less than $50 \%$. Therefore, there are no problems in the results of the reliability and validity tests.

Table 2. The Results of the Reliability and Validity tests.

\begin{tabular}{|c|c|c|c|c|c|c|c|}
\hline \multirow[t]{2}{*}{ Items } & \multicolumn{3}{|c|}{ EFA Results } & \multicolumn{4}{|c|}{ CFA Results } \\
\hline & $\begin{array}{c}\text { Factor } \\
\text { Loading }\end{array}$ & $\begin{array}{c}\text { Validity } \\
\text { Reliability }\end{array}$ & $\begin{array}{c}\text { Bartlett \& } \\
\text { KMO }\end{array}$ & $\begin{array}{c}\text { Factor } \\
\text { Loading }\end{array}$ & AVE & $\begin{array}{c}\text { Critical } \\
\text { Ratio }\end{array}$ & Goodness of Fit \\
\hline $\begin{array}{l}\text { iss } 1 \\
\text { iss } 2 \\
\text { iss } 3 \\
\text { iss } 4 \\
\text { iss } 5 \\
\text { iss } 6 \\
\text { iss } 7\end{array}$ & $\begin{array}{l}0.815 \\
0.878 \\
0.810 \\
0.757 \\
0.683 \\
0.609 \\
0.739\end{array}$ & $\begin{array}{c}\text { C: } 0.894 \\
\text { E: } 4.319 \\
\text { V: } 22.732\end{array}$ & 85 & $\begin{array}{l}0.850 \\
0.966 \\
0.786 \\
0.611 \\
0.580 \\
0.584 \\
0.540\end{array}$ & 0.592 & $\begin{array}{l}7.269^{* * *} \\
7.512^{* * *} \\
6.939 * * * \\
7.171^{* * *} \\
7.483^{* * *} \\
6.509^{* * *} \\
-\end{array}$ & $\begin{array}{c}\text { Chi }=126.827 \\
\text { df }=100 \\
p=0.036 \\
\mathrm{Q}=1.268 \\
\mathrm{GFI}=0.927 \\
\mathrm{AGFI}=0.860 \\
\mathrm{CFI}=0.988 \\
\text { RMSEA }=0.041\end{array}$ \\
\hline $\begin{array}{l}\text { msu } 1 \\
\text { msu } 2 \\
\text { msu } 3 \\
\text { msu } 4 \\
\text { msu } 5\end{array}$ & $\begin{array}{l}0.780 \\
0.844 \\
0.863 \\
0.856 \\
0.841\end{array}$ & $\begin{array}{c}C: 0.912 \\
E: 3.786 \\
V: 19.927\end{array}$ & $\begin{array}{c}\text { Bartlett test } \\
\text { Chi }=2374.824 \\
\text { df }=171 \\
p=0.000\end{array}$ & $\begin{array}{l}0.740 \\
0.783 \\
0.889 \\
0.824 \\
0.778\end{array}$ & 0.695 & $\begin{array}{c}9.834^{* * *} \\
10.390^{* * *} \\
12.202^{* * *} \\
14.802^{* * *} \\
-\end{array}$ & \\
\hline $\begin{array}{l}\operatorname{coo} 1 \\
\operatorname{coo} 2 \\
\operatorname{coo} 3 \\
\operatorname{coo} 4 \\
\operatorname{coo} 5 \\
\operatorname{coo} 6 \\
\operatorname{coo} 7\end{array}$ & $\begin{array}{l}0.710 \\
0.812 \\
0.862 \\
0.853 \\
0.827 \\
0.894 \\
0.762\end{array}$ & $\begin{array}{c} \\
\text { C: } 0.935 \\
\text { E: } 5.133 \\
\text { V: } 27.018\end{array}$ & & $\begin{array}{l}0.681 \\
0.764 \\
0.867 \\
0.876 \\
0.832 \\
0.885 \\
0.736\end{array}$ & 0.700 & $\begin{array}{c}8.467^{* * *} \\
9.975^{* * *} \\
11.338^{* * *} \\
11.462^{* * *} \\
10.767^{* * *} \\
13.684^{* * *} \\
-\end{array}$ & \\
\hline
\end{tabular}

Note: iss: information systems of shipping and logistics firms, msu: managers' support for new technology such as blockchains, coo: cooperation with shippers; C: Cronbach's alpha; E: eigenvalue; V: percentage of variance; KMO: Kaiser-Meyer-Olkin; Chi: Chi-square; df: degrees of freedom; ${ }^{* * *}:<0.01$. 
Table 3 shows the result of correlation analysis among the variables. There are two meanings of the results. One is correlations between independent variables and dependent variables. Information systems and managers' support are confirmed as the variables to explain cooperation, and the relationships between the variables are positive correlations. The other is that if there are the high levels of correlations between independent variables, multicollinearity is doubted. However, information systems are an independent variable and managers' support is an interaction factor in this study, and as a result, there is no need to verify multicollinearity because the dimensions are different. Therefore, there is no problem in the result of the correlation analysis.

Table 3. Correlation Analysis Results.

\begin{tabular}{cccccc}
\hline Variable & Average & S.D. & Iss & Msu & Coo \\
\hline iss & 4.677 & 1.051 & 1.000 & & \\
\hline msu & 5.199 & 1.086 & $\begin{array}{c}0.265^{* * *} \\
(0.070)\end{array}$ & 1.000 \\
\hline coo & 5.288 & 1.062 & $\begin{array}{c}0.426^{* * *} \\
(0.181)\end{array}$ & $\begin{array}{c}0.398^{* * *} \\
(0.158)\end{array}$ & 1.000
\end{tabular}

Note: ${ }^{* *}<0.01$; S.D.: standard deviation, iss: information systems of shipping and logistics firms, msu: managers support for new technology such as blockchains, coo: cooperation with shippers; The number in the parentheses is the square of the correlation coefficient.

\subsection{The Results of Hypotheses Tests}

To achieve the objective, this study analyzes the interaction effect of the variables to use MRA. Next is the result.

Table 4 shows the result of hypotheses tests. Model I explains that information systems of shipping and logistics firms positively affect cooperation with shippers $(\mathrm{H}$. 1 is supported). In addition, the results of MRA explain that the R-square of model III (0.271) is higher than the R-squares of model I (0.176) and model II (0.260). Statistically, if the R-squares of model I and model II are the same and the R-square of model III is higher than the others, there is a pure interaction effect. However, if the R-square of model II is higher than the R-square of model I and the R-square of model III is the highest, there is a quasi-interaction effect. As a result, the interaction variable has a positive influence on cooperation in model III, and the R-square of model III is the highest (H. 2 is supported). Therefore, there is a quasi-interaction effect of information systems of shipping and logistics firms and managers' support for new technology such as blockchains on cooperation with shippers.

Table 4. Hypotheses Tests.

\begin{tabular}{|c|c|c|c|}
\hline Variable & Model I & Model II & Model III \\
\hline Constant & $\begin{array}{c}3.275 \\
\left(9.422^{* * *}\right)\end{array}$ & $\begin{array}{c}2.101 \\
\left(4.929^{* * *}\right)\end{array}$ & $\begin{array}{c}-0.082 \\
(-0.066)\end{array}$ \\
\hline iss $(X)$ & $\begin{array}{c}0.431 \\
\left(5.937^{* * *}\right)\end{array}$ & $\begin{array}{c}0.348 \\
\left(4.885^{* * *}\right)\end{array}$ & $\begin{array}{c}0.878 \\
\left(3.007^{* * *}\right)\end{array}$ \\
\hline $\mathrm{msu}(\mathrm{W})$ & & $\begin{array}{c}0.300 \\
\left(4.345^{* * *}\right)\end{array}$ & $\begin{array}{c}0.710 \\
\left(3.088^{* * *}\right)\end{array}$ \\
\hline inte $(\mathrm{X} \times \mathrm{W})$ & & & $\begin{array}{c}0.099 \\
(1.870 *)\end{array}$ \\
\hline F & $35.244^{* * *}$ & $29.045^{* * *}$ & $20.834^{* * *}$ \\
\hline $\mathrm{R} 2$ & 0.181 & 0.269 & 0.285 \\
\hline adj R2 & 0.176 & 0.260 & 0.271 \\
\hline
\end{tabular}

Note: ${ }^{* *}:<0.01,{ }^{*}:<0.1$; iss: information systems of shipping and logistics firms, msu: managers' support for new technology such as blockchain, inte: an interaction variable. 


\subsection{Discussion}

Next is the discussion of the above results. First, information systems of shipping and logistics firms positively affect cooperation with shippers. According to a resource-based view, information systems of shipping and logistics firms are useful resources to have a direct influence on cooperation with sippers. Moreover, information systems created for cooperation with shippers have various characteristics such as rareness because competitors do not easily buy information systems in the market, inimitability because competitors do not perfectly imitate it, and non-substitution because it is not substituted as other resources in the market. The information systems which have the characteristics, such as tangible resources, are treated as a strategic resource which has ambiguity in the causal relations with performance and social complexity in the resources and capabilities. As a result of strengthening the strategic resources, they can increase cooperation with shippers on the basis of staff education and logistics process improvement. Therefore, the relationship between information systems of shipping and logistics firms as a strategic resource and cooperation with shippers can be explained from a resource-based view.

Second, a resource-based view can explain the interaction effect of information systems of shipping and logistics firms and managers' support for new technology such as blockchains on cooperation with shippers. Information systems are a resource for shipping and logistics firms, and to use these systems, managers should encourage and reward staff. The staff is afraid of change and as a result, resists it. The resistance is connected with conflicts and this is the factor that prevents the achievement of goals in firms. To minimize the resistance and conflicts, managers should suggest directions to minimize the resistance against new technology through staff education and to acquire new technology by themselves through reward systems when new technology such as blockchains emerge. The emergence of new technology such as blockchains means a change in environment, and staff members who adapt to the change become superior resources. Because the staff can demonstrate the capability within the firms, the resources are limited in movement in the market. In this regard, firms which have superior resources compared with competitors neutralize changes in the environment caused by the emergence of the new technology through the heterogeneity and immobility of resources and enhance performance through sustainable learning and logistics process improvement. Therefore, shipping and logistics firms should educate staff to quickly respond to the change through managers' support for new technology such as blockchains as well as improving information systems, followed by enhanced cooperation with shippers.

\section{Conclusions}

The objective of this study was to analyze the interaction effect of information systems of shipping and logistics firms and managers' support for new technology such as blockchains on cooperation with shippers. To achieve the objective, this study extracted variables from prior research, and a questionnaire was sent to Korean shipping and logistics firms. The reliability and validity of the collected data were analyzed by Cronbach's alpha coefficients and a factor analysis, and hypotheses were tested by MRA. The theoretical implications are shown in the discussion, and next is managerial implications, limitations, and the directions for future research.

Managerial implications are as follows. First, shipping and logistics firms use information systems to collaborate with shippers. For this reason, managers develop information systems which add value to logistics processes and efficiently use these in logistics operations. The information systems of shipping and logistics firms have the characteristics of timeliness, accuracy, accessibility, information exchange, immediacy, flexibility, and information sharing in the cooperative work with shippers. The firms which have information systems enable operational cooperation with shippers, perform efficient and standardized information sharing, and increase operational efficiency through cooperation with shippers. Therefore, managers of shipping and logistics firms encourage staff to use information systems, followed by efficient cooperation with shippers. 
Second, information systems of shipping and logistics firms positively affect cooperation with shippers. However, there is a time lag between applications of information systems and improvement of performance. To reduce the time lag, managers of shipping and logistics firms should provide staff with support for new technology such as blockchains, and as a result of the support, staff can closely collaborate with shippers. In particular, new technology such as blockchains is quickly introduced into the market on the basis of changes in the technological environment. In this case, staff can resist new technology and conflicts can arise within firms. To solve the problems, managers can disseminate new technology to the internal systems through learning and reward systems for staff. Therefore, shipping and logistics firms efficiently collaborate with shippers on the basis of managers' support for new technology such as blockchains as well as superior information systems.

Despite the above implications, this study has limitations. First, there are various factors which have an effect on cooperation between shipping and logistics firms and shippers, which can be divided into viewpoints such as environmental, corporate internal, and technological. This study verified the relationships between information systems, managers' support and cooperation from the technological viewpoint. However, a study on cooperation between shipping and logistics firms and shippers is needed with respect to the various viewpoints. Second, there are many firms in the port logistics process. This study verified the relationship between shipping and logistics firms and shippers, but we need to analyze the relationships between various port logistics firms such as container terminals, bonded warehouses, customs brokers, bonded transporters, and inland transporters. The limitations are the directions for future research.

Funding: This research was supported by 2020 Academic-research Cooperation Program in Korea Maritime Institute (KMI).

Institutional Review Board Statement: Not applicable.

Informed Consent Statement: Not applicable.

Data Availability Statement: Not Applicable.

Conflicts of Interest: The author declares no conflict of interest.

\section{Appendix A}

Table A1. The Questionnaire.

\begin{tabular}{|c|c|}
\hline Variables & Items \\
\hline $\begin{array}{l}\text { Information systems of } \\
\text { shipping and logistics firms }\end{array}$ & $\begin{array}{l}\text { We can get information when we need it. } \\
\text { We can get accurate information that matches the situation. } \\
\text { We can access to information at any time. } \\
\text { We manage and exchange standardized information. } \\
\text { We have the availability of information at any time. } \\
\text { We provide flexible information to meet the needs of shippers. } \\
\text { We freely share information with shippers. }\end{array}$ \\
\hline $\begin{array}{l}\text { Managers' support for } \\
\text { blockchain technology }\end{array}$ & $\begin{array}{l}\text { Managers emphasize learning about new technology such as blockchain to identify the needs of shippers. } \\
\text { Managers provide staff with education on new technology such as blockchain which is available in the } \\
\text { relationships with shippers. } \\
\text { Managers improve logistics processes to use new technology such as blockchain when staff works with shippers. } \\
\text { Managers support to making new technology such as blockchain which is necessary for communication with } \\
\text { shippers. } \\
\text { Managers encourage the usage of new technology such as blockchain to check the relationships with shippers. }\end{array}$ \\
\hline Cooperation with shippers & $\begin{array}{l}\text { We have an integrated database with shippers which is related to works. } \\
\text { We are effectively sharing information with shippers. } \\
\text { We have the capabilities of standardized information sharing with shippers. } \\
\text { We operate cooperative logistics processes with shippers. } \\
\text { We operate logistics processes on the basis of the integrated principle with shippers. } \\
\text { We have the integrated criteria for measuring performance with shippers. } \\
\text { We increase operational efficiency through cooperation with shippers. }\end{array}$ \\
\hline
\end{tabular}




\section{References}

1. Bae, H.S. The Relationships between Orientation, Collaboration and Performance for Supply Chain Management of Korean FDI Firms for Sustainable Growth. Sustainability 2020, 12, 10311. [CrossRef]

2. Salleh, N.A.M.; Jusoh, R.; Isa, C.R. Relationship between Information Systems Sophistication and Performance Measurement. Ind. Manag. Data Syst. 2010, 110, 993-1017. [CrossRef]

3. Robert, M.; Wood, M. The Strategic Use of Computerized Information Systems by a Micro Enterprise. Logist. Inf. Manag. 2002, 15, 115-125. [CrossRef]

4. Bae, H.S. The Interaction Effect of Strategic Information Systems on Performance of International Freight Forwarders: An Analysis of Gaps in Performance. Asian J. Shipp. Logist. 2019, 35, 108-117. [CrossRef]

5. Selvaraju, M.; Beleya, P.; Sundram, V.P.K. Supply Chain Cost reduction using mitigation and resilient strategies in the hypermarket retail business. Int. J. Supply Chain Manag. 2017, 6, 116-121.

6. Olorunniwo, F.O.; Li, X. Information Sharing and Collaboration Practices in Reverse Logistics. Supply Chain Manag. Int. J. 2010, 15, 454-462. [CrossRef]

7. Titus, S.; Brochner, J. Managing Information Flow in Construction Supply Chains. Constr. Innov. Inf. Process. Manag. 2005, 5, 71-82. [CrossRef]

8. Sundram, V.P.K.; Bahrin, A.S.; Munir, Z.B.A.; Zolait, A.H. The Effect of Supply Chain Information Management and Information System Infrastructure: The Mediating Role of Supply Chain Integration toward Manufacturing Performance in Malaysia. J. Enterp. Inf. Manag. 2018, 31, 751-770. [CrossRef]

9. Kim, J.S.; Shin, N. The Impact of Blockchain Technology Application on Supply Chain Partnership and Performance. Sustainability 2019, 11, 6181. [CrossRef]

10. Larsson, J.; Larsson, L. Integration, Application and Importance of Collaboration in Sustainable Project Management. Sustainability 2020, 12, 585. [CrossRef]

11. Shin, N.; Park, S.H.; Park, S. Partnership-based Supply Chain Collaboration: Impact on Commitment, Innovation and Firm Performance. Sustainability 2019, 11, 449. [CrossRef]

12. Chiu, H.N. The Integrated Logistics Management Systems: A Framework and Case Study. Int. J. Phys. Distrib. Logist. Manag. 1995, 25, 4-22. [CrossRef]

13. Closs, D.J.; Xu, K. Logistics Information Technology Practice in Manufacturing and Merchandising Firms. Int. J. Phys. Distrib. Logist. Manag. 2000, 30, 869-886. [CrossRef]

14. Lee, S.M.; Kim, B.O. Developing the Information Systems Architecture for World-class Organizations. Manag. Decis. 1996, 34, 46-52. [CrossRef]

15. Bian, Y.; Kang, L.; Zhao, J.L. Dual Decision-making with Discontinuance and Acceptance of Information Technology: The Case of Cloud Computing. Internet Res. 2020, 30, 1521-1546. [CrossRef]

16. Chen, S.S.; Yang, C.O.; Chou, T.C. Developing SCM Framework Associated with IT-enabled SC Network Capabilities. Int. J. Phys. Distrib. Logist. Manag. 2017, 47, 820-842. [CrossRef]

17. Chow, C.W.; Wu, A.; Yuen, S. The Benefits and Determinants of Success in Information Technology Applications in a Greater China Context: Exploratory Evidence from Taiwanese Manufacturing Companies. Manag. Financ. 2003, 29, 14-31. [CrossRef]

18. Lambert, D.M.; Stock, J.R.; Ellram, L.M. Fundamentals of Logistics Management; McGraw-Hill: Boston, MA, USA, 1998.

19. Yeh, C.H.; Lee, G.G.; Pai, J.C. How Information System Capability Affects E-business Information Technology Strategy Implementation: An Empirical Study in Taiwan. Bus. Process Manag. J. 2012, 18, 197-218. [CrossRef]

20. Jeffers, P. Embracing Sustainability: Information Technology and the Strategic Leveraging of Operations in Third-party Logistics. Int. J. Oper. Prod. Manag. 2010, 30, 260-287. [CrossRef]

21. Leek, C. Information Systems Frameworks and Strategy. Ind. Manag. Data Syst. 1997, 97, 86-89. [CrossRef]

22. Yoon, H.K. An Empirical Study to the Logistics Information's Influence to Enterprise Results: With Emphasis on the Iron Steel Industry. Korean Logist. Rev. 2002, 12, 101-122.

23. Bag, S.; Viktorovich, D.A.; Sahu, A.K.; Sahu, A.K. Barriers to Adoption of Blockchain Technology in Gerrn Supply Chain Management. J. Glob. Oper. Strateg. Sourc. 2021, 14, 104-133. [CrossRef]

24. Rejeb, A.; Keogh, J.G.; Simske, S.J.; Stafford, T.; Treiblmaier, H. Potentials of Blockchain Technology for Supply Chain Collaboration: A Conceptual Framework. Int. J. Logist. Manag. 2021. [CrossRef]

25. Tsiulin, S.; Reinau, K.H.; Hilmola, O.P.; Goryaev, N.; Karam, A. Blockchain-based Applications in Shipping and Port Management: A Literature Review towards Defining Key Conceptual Frameworks. Rev. Int. Bus. Strategy 2020, 30, 201-224. [CrossRef]

26. Jabbar, K.; Bjørn, P. Infrastructural Grind: Introducing Blockchain Technology in the Shipping Domain. In Proceedings of the 2018 ACM Conference, Sanibel Island, FL, USA, 7-10 January 2018; pp. 297-308.

27. Koji, T. Blockchain Technology and Electronic Bill of Lading. J. Int. Marit. Law 2016, 22, 202-211.

28. Mollenkopf, D.; Gibson, A.; Ozanne, L. The Integration of Marketing and Logistics Functions: An Empirical Examination of New Zealand Firms. J. Bus. Logist. 2000, 21, 89-112.

29. Stevens, G.C. Integrating the Supply Chain. Int. J. Phys. Distrib. Logist. Manag. 1989, 19, 3-8. [CrossRef]

30. Kahn, K.B.; Mentzer, J.T. Marketing's Integration with Other Departments. J. Bus. Res. 1998, 42, 53-62. [CrossRef] 
31. Bae, H.S. Investigating the Effect of Environmental Uncertainty on Supply Chain Collaboration and Operational Performance. Ph.D. Thesis, University of Hull, Hull City, UK, June 2014.

32. Min, S.; Roath, A.S.; Daugherty, P.J.; Genchev, S.E.; Chen, H.; Arndt, D.; Richey, R.G. Supply Chain Collaboration: What's Happening? Int. J. Logist. Manag. 2005, 16, 237-256. [CrossRef]

33. Closs, D.J.; Goldsby, T.J.; Clinton, S.R. Information Technology Influence on World Class Logistics Capability. Int. J. Phys. Distrib. Logist. Manag. 1997, 27, 4-17. [CrossRef]

34. Barney, J. Firm Resources and Sustained Competitive Advantage. J. Manag. 1991, 17, 99-120. [CrossRef]

35. Markides, C.C.; Williamson, P. Corporate Diversification and Organizational Structure: A Resource-based View. Acad. Manag. J. 1996, 39, 340-367.

36. Amit, R.; Schoemaker, P.J. Strategic Asserts and Organizational Rent. Strateg. Manag. J. 1993, 14, 33-46. [CrossRef]

37. Clegg, C.; Axtell, C.; Damodaran, L.; Farbey, B.; Hull, R.; Lloyd-Jones, R.; Sell, R.; Tomlison, C. Information Technology: A Study of Performance and the Role of Human and Organizational Factors. Ergonomics 1997, 40, 851-871. [CrossRef]

38. Rodrigues, A.M.; Stank, T.P.; Lynch, D.F. Linking Strategy, Structure, Process and Performance in Integrated Logistics. J. Bus. Logist. 2004, 25, 65-94. [CrossRef]

39. Iyer, K.N.S. Demand chain collaboration and operational performance: Role of IT Analytic Capability and Environmental Uncertainty. J. Bus. Ind. Mark. 2011, 26, 81-91. [CrossRef]

40. Paulraj, A.; Chen, I.J. Strategic Buyer-supplier Relationships, Information Technology and External Logistics Integration. J. Supply Chain Manag. 2007, 43, 2-14. [CrossRef]

41. Gustin, C.M.; Daugherty, P.J.; Stank, T.P. The Effect of Information Availability on Logistics Integration. J. Bus. Logist. 1995, 16, $1-21$.

42. Narasimhan, R.; Kim, S.W. Information System Utilization Strategy for Supply Chain Integration. J. Bus. Logist. 2001, 22, 51-75. [CrossRef]

43. Daugherty, P.J.; Ellinger, A.E.; Gustin, C.M. Integration Logistics: Achieving Logistics Performance Improvements. Supply Chain Manag. Int. J. 1996, 1, 25-33. [CrossRef]

44. Clinton, S.R. Context-Strategy-Structure-Performance in Logistics: A Contingency Approach. Ph.D. Thesis, Michigan State University, East Lansing, MI, USA, 1997.

45. Ellinger, A.E.; Daugherty, P.J.; Keller, S.B. The Relationship between Marketing/Logistics Interdepartment Integration and Performance in U.S. Manufacturing Firms: An Empirical Study. J. Bus. Logist. 2000, 21, 1-22.

46. Stank, T.P.; Keller, S.B.; Daugherty, P.J. Supply Chain Collaboration and Logistical Service Performance. J. Bus. Logist. 2001, 22, 29-48. [CrossRef]

47. O'Leary-Kelly, S.W.; Vokurka, R.J. The Empirical Assessment of Construct Validity. J. Oper. Manag. 1998, 16, 387-405. [CrossRef]

48. Segars, A. Assessing the Unidimensionality of Measurement: A Paradigm and Illustration within the Context of Information System Research. Omega 1997, 25, 107-121. [CrossRef] 